\title{
Morphological selection of human spermatozoa in vivo and in vitro
}

\author{
D. Mortimer*, E. E. Leslie, R. W. Kelly† and A. A. Templeton \\ Department of Obstetrics \& Gynaecology and $\dagger$ M.R.C. Reproductive Biology Unit, \\ University of Edinburgh, Centre for Reproductive Biology, 37 Chalmers Street, \\ Edinburgh EH3 9EW, U.K.
}

\begin{abstract}
Summary. Light microscopic assessment of human spermatozoa in post-coital samples of cervical mucus revealed a significant improvement in the general sperm morphology between the semen and the cervix. Further analysis showed that the excluded spermatozoa were more likely to be those with midpiece or tail defects that impaired motility. Significant changes were also found when the morphology of spermatozoa recovered from the uterus and Fallopian tubes following AIH was compared with the semen used for insemination: in the semen, uterus and oviducts there were respectively 53,77 and $71 \%$ spermatozoa with completely normal morphology, and 12,3 and $0.6 \%$ spermatozoa with defects of the midpiece and/or tail (as assessed by surface replica electron microscopy). Selection of spermatozoa in vitro by allowing them to swim upwards through a nickel mesh also reduced the number of spermatozoa with abnormal morphology, particularly of the midpiece and tail. It is concluded that the apparent selection of morphologically normal spermatozoa is not a direct function of the female tract, but that the spermatozoa can effect their own selection because of their differential motility.
\end{abstract}

\section{Introduction}

The ability of the human cervix and its mucus to exclude many of the morphologically abnormal spermatozoa which abound even in the semen of fertile men has long been recognized (Bergman, 1955; Botella-Llusia, 1956). These authors postulated that the selection was due to the quality of the motility of the spermatozoa, while others have suggested the possible existence of a physical filter (e.g. Davajan, Nakamura \& Kharma, 1970; Moghissi, 1977). Subsequent studies on the morphology of human spermatozoa in cervical mucus (Clavert, Brun \& Bollecker, 1975; Fredricsson \& Björk, 1977; Perry, Glezerman \& Insler, 1977) have expanded the earlier findings, but do not agree as to the effectiveness of the 'barrier' of cervical mucus against the migration of spermatozoa with abnormal head forms.

Observations on the morphology of human spermatozoa recovered from the higher regions of the female tract (Fallopian tubes) and the peritoneal cavity are very few. Ahlgren, Boström \& Malmqvist (1974) found that spermatozoa recovered from the ampulla, fimbria and pouch of Douglas were consistently of better morphology than those in the ejaculate. Asch (1976) found no morphologically abnormal forms among spermatozoa recovered from the fimbria and pouch of Douglas.

The existence of a morphological selection of spermatozoa within the human female

* Present address: Department of Obstetrics \& Gynaecology, University of Birmingham, Birmingham Maternity Hospital, Edgbaston, Birmingham B15 2TG, U.K. 
reproductive tract is now generally accepted, but although sperm motility has often been suggested to be the causal mechanism (for review see Mortimer, 1978), absolute proof does not exist. This paper reports the results of two studies of sperm selection within the human female tract, and a third study designed to duplicate this selection in vitro where its basis might be determined.

\section{Materials and methods}

\section{Study 1: Post-coital test material}

Sixteen couples undergoing infertility investigations were recruited and, after a requested period of sexual abstinence of $\geqslant 3$ days, presented for a routine post-coital test on the anticipated day of ovulation (from previous menstrual data) at times varying between 1 and $6 \frac{1}{2} \mathrm{~h}$ post coitum. Subsequently 7 couples had to be excluded because of inadequate numbers of spermatozoa for morphological assessment in the mucous samples. For the remaining 9 couples, permanent stained smears (Papanicolaou, 1942) were made of the cervical material, and also of ejaculated semen obtained from the husbands as close to the time of investigation as possible. All slides (one semen and one mucus per couple) were randomized and coded before scoring, when 500 spermatozoa were assessed from each slide at a magnification of $\times 1000$ under oil immersion by bright-field illumination using a Leitz Ortholux 1 microscope. A 'normal' spermatozoon was defined as one having the modal oval-shaped head (see Eliasson, 1975) with recognizable acrosomal and post-acrosomal regions, no evidence of defects of the midpiece or flagellum, and no residual cytoplasmic droplet. By Papanicolaou staining, abnormal midpieces are coloured red, and cytoplasmic droplets green. All the morphological assessments were made by one observer (D. M.).

\section{Results}

As shown in Table 1, the percentage relative change in normal spermatozoa was positive in all but one couple (Test $G$ ), and was significant in all but two (Tests $G$ and $H$ ). The various types of morphologically abnormal spermatozoa, and their incidences in each of the 9 tests are presented in Table 2. From the $2 \times 2 \chi^{2}$ analyses of the summed totals there were significant changes in the incidence of all categories of sperm morphology between the semen and the cervical mucus.

Table 1. Percentage of spermatozoa with normal morphology in the semen and postcoital cervical mucus of 9 couples

\begin{tabular}{cccc}
\hline & \multicolumn{2}{c}{ \% normal spermatozoa } & \\
\cline { 2 - 3 } Patient & Semen & Cervix & $\begin{array}{c}\text { relative } \\
\text { change }\end{array}$ \\
\hline A & 60.8 & 76.8 & $+26.3^{*}$ \\
B & 49.2 & 74.2 & $+50.8^{*}$ \\
C & 52.8 & 90.4 & $+712^{*}$ \\
D & 49.4 & 81.2 & $+64.4^{*}$ \\
E & 66.8 & 82.4 & $+23.4^{*}$ \\
F & 62.8 & 74.8 & $+19.1^{*}$ \\
G & 82.6 & 79.6 & -3.6 \\
H & 69.2 & 73.4 & +6.1 \\
I & 65.4 & 79.2 & $+21.1^{*}$ \\
\hline Mean & 62.1 & 79.1 & $+31.0^{*}$ \\
\pm s.e.m. & \pm 3.6 & \pm 1.8 & \pm 8.6 \\
\hline
\end{tabular}

* $P<0.001\left(2 \times 2 \chi^{2}\right.$ tests on actual counts $)$. 
Table 2. Numbers of spermatozoa of the various morphological categories scored in the ejaculates and post-coital cervical mucus of 9 couples

\begin{tabular}{|c|c|c|c|c|c|c|c|c|c|c|c|c|}
\hline \multirow[b]{2}{*}{ Morphology } & \multirow[b]{2}{*}{ Source } & \multicolumn{9}{|c|}{ Patient No. } & \multirow[b]{2}{*}{ Total } & \multirow{2}{*}{$\begin{array}{c}\% \text { relative } \\
\text { change }\end{array}$} \\
\hline & & 1 & 2 & 3 & 4 & 5 & 6 & 7 & 8 & 9 & & \\
\hline Normal & $\begin{array}{l}\text { Semen } \\
\text { Cervix }\end{array}$ & $\begin{array}{l}304 \\
384\end{array}$ & $\begin{array}{l}246 \\
371\end{array}$ & $\begin{array}{l}264 \\
452\end{array}$ & $\begin{array}{l}247 \\
406\end{array}$ & $\begin{array}{l}334 \\
412\end{array}$ & $\begin{array}{l}314 \\
374\end{array}$ & $\begin{array}{l}413 \\
398\end{array}$ & $\begin{array}{l}346 \\
367\end{array}$ & $\begin{array}{l}327 \\
396\end{array}$ & $\begin{array}{l}2795 \\
3560\end{array}$ & $+27 \cdot 4^{*}$ \\
\hline Immature & $\begin{array}{l}\text { Semen } \\
\text { Cervix }\end{array}$ & $\begin{array}{r}59 \\
8\end{array}$ & $\begin{array}{l}22 \\
15\end{array}$ & $\begin{array}{r}57 \\
0\end{array}$ & $\begin{array}{r}28 \\
8\end{array}$ & $\begin{array}{l}4 \\
1\end{array}$ & $\begin{array}{l}38 \\
20\end{array}$ & $\begin{array}{l}11 \\
21\end{array}$ & $\begin{array}{r}13 \\
0\end{array}$ & $\begin{array}{l}24 \\
13\end{array}$ & $\begin{array}{r}256 \\
86\end{array}$ & $-66 \cdot 4^{*}$ \\
\hline $\begin{array}{l}\text { Abnormal } \\
\text { head }\end{array}$ & $\begin{array}{l}\text { Semen } \\
\text { Cervix }\end{array}$ & $\begin{array}{r}103 \\
98\end{array}$ & $\begin{array}{r}103 \\
87\end{array}$ & $\begin{array}{r}120 \\
7\end{array}$ & $\begin{array}{l}91 \\
65\end{array}$ & $\begin{array}{r}149 \\
71\end{array}$ & $\begin{array}{r}106 \\
90\end{array}$ & $\begin{array}{l}71 \\
75\end{array}$ & $\begin{array}{l}83 \\
66\end{array}$ & $\begin{array}{r}120 \\
82\end{array}$ & $\begin{array}{l}946 \\
641\end{array}$ & $-32 \cdot 2^{*}$ \\
\hline $\begin{array}{l}\text { Abnormal } \\
\text { midpiece }\end{array}$ & $\begin{array}{l}\text { Semen } \\
\text { Cervix }\end{array}$ & $\begin{array}{l}7 \\
0\end{array}$ & $\begin{array}{l}89 \\
17\end{array}$ & $\begin{array}{l}38 \\
41\end{array}$ & $\begin{array}{r}112 \\
19\end{array}$ & $\begin{array}{l}0 \\
5\end{array}$ & $\begin{array}{r}31 \\
0\end{array}$ & $\begin{array}{l}0 \\
0\end{array}$ & $\begin{array}{r}9 \\
58\end{array}$ & $\begin{array}{r}18 \\
0\end{array}$ & $\begin{array}{l}304 \\
140\end{array}$ & $-53 \cdot 9^{*}$ \\
\hline $\begin{array}{l}\text { Tail } \\
\text { defect }\end{array}$ & $\begin{array}{l}\text { Semen } \\
\text { Cervix }\end{array}$ & $\begin{array}{r}21 \\
6\end{array}$ & $\begin{array}{l}38 \\
10\end{array}$ & $\begin{array}{r}19 \\
0\end{array}$ & $\begin{array}{r}18 \\
2\end{array}$ & $\begin{array}{l}9 \\
9\end{array}$ & $\begin{array}{r}9 \\
16\end{array}$ & $\begin{array}{l}1 \\
6\end{array}$ & $\begin{array}{r}45 \\
9\end{array}$ & $\begin{array}{l}9 \\
7\end{array}$ & $\begin{array}{r}169 \\
65\end{array}$ & $-61 \cdot 5^{*}$ \\
\hline $\begin{array}{l}\text { Conjoined } \\
\text { spermatozoa }\end{array}$ & $\begin{array}{l}\text { Semen } \\
\text { Cervix }\end{array}$ & $\begin{array}{l}6 \\
4\end{array}$ & $\begin{array}{l}2 \\
0\end{array}$ & $\begin{array}{l}2 \\
0\end{array}$ & $\begin{array}{l}4 \\
0\end{array}$ & $\begin{array}{l}4 \\
2\end{array}$ & $\begin{array}{l}2 \\
0\end{array}$ & $\begin{array}{l}4 \\
0\end{array}$ & $\begin{array}{l}4 \\
0\end{array}$ & $\begin{array}{l}2 \\
2\end{array}$ & $\begin{array}{r}30 \\
8\end{array}$ & $-73 \cdot 3^{*}$ \\
\hline
\end{tabular}

Significant changes were determined by $2 \times 2 \chi^{2}$ tests; $* P<0.001$.

\section{Materials and methods}

\section{Study 2: Uterine and tubal material}

Material from 5 women who consented to have AIH (between $3 \frac{1}{2}$ and $11 \mathrm{~h}$ ) before surgery was used in this study: one patient was undergoing hysterectomy for menorrhagia, 2 patients were having salpingectomy for elective sterilization, and 2 women were undergoing diagnostic laparoscopy as part of their infertility investigations. The procedure was scheduled to coincide with ovulation from previous menstrual data, and in each case the female pelvic organs were anatomically normal at inspection. In all patients the uterus was flushed trans-cervically using a 3-way balloon catheter (modified from Maathuis \& Aitken, 1978); for Patient 1 the uterus was flushed after excision. Fallopian tube material was obtained from Patients 1, 2 and 3, ampullary and isthmic material for each patient being combined in view of the expected very small numbers of spermatozoa at this level of the female tract (Ahlgren et al., 1974). For all material, the flushings (medium 199 with Earle's salts and Hepes buffer: Flow Labs, Irvine, U.K.) were concentrated by centrifugation $(500 \mathrm{~g}, 10 \mathrm{~min})$ and resuspended in $1.0 \mathrm{ml}$ fresh medium before fixation with buffered glutaraldehyde and processing for surface replication (for details of method see Mortimer, 1981). Surface replication was chosen for the morphological assessment of these spermatozoa as a method which would provide the most detailed and reliable information on this valuable material (Mortimer, 1981). Aliquots of each ejaculate used for AIH were also processed for surface replication and used for comparison with the uterine and tubal spermatozoa.

Replicas were searched at a magnification of $\times 1500$ or $\times 3000$ in an AEI EM6B transmission electron microscope operating at an accelerating voltage of $60 \mathrm{kV}$. The morphology of each spermatozoon found was assessed (by D.M.) at magnifications between $\times 7500$ and $\times 30000$; explanatory micrographs of some of the sperm abnormalities identifiable by this technique are presented in Plate 1.

\section{Results}

These are shown in Table 3. Any spermatozoa classified as 'disintegrating', and hence of unknown original morphology, were included in the analysis as abnormal. These spermatozoa 
were presumably undergoing post-mortem autolysis, or phagocytic degradation when flushed from the tract. In spite of this potential bias away from a selection for normal spermatozoa, and the relatively small numbers of spermatozoa available for evaluation, most of the differences between the semen and uterus and between the semen and Fallopian tubes were significant (Table 3).

Table 3. Distribution of normal and abnormal spermatozoa in tubal samples from 5 couples after AIH (disintegating spermatozoa were counted as abnormal forms, and spermatozoa with simple coiled tails were not included as being abnormal)

\begin{tabular}{|c|c|c|c|c|c|c|c|c|c|c|}
\hline \multirow[b]{2}{*}{ Patient } & \multirow[b]{2}{*}{ Type } & \multicolumn{3}{|c|}{ Semen } & \multicolumn{3}{|c|}{ Uterus } & \multicolumn{3}{|c|}{ Oviducts } \\
\hline & & No. & Normal & Abnormal & No. & Normal & Abnormal & No. & Normal & Abnormal \\
\hline 1 & H & 300 & 137 & 47 & 100 & $71 \S$ & $5 t$ & 100 & $73 \S$ & 0 \\
\hline 2 & $\mathrm{~S}$ & 200 & 135 & 25 & 11 & $10^{\circ}$ & 0 & 61 & $45^{\circ}$ & $1^{*}$ \\
\hline 3 & S & 200 & 92 & 20 & 2 & 2 & 0 & 12 & 6 & 0 \\
\hline 4 & L & 200 & 112 & 11 & 41 & $32 \dagger$ & 0 & - & - & - \\
\hline 5 & $\mathbf{L}$ & 200 & 108 & 26 & 17 & $16 \ddagger$ & 0 & - & - & - \\
\hline 1-5 Totals & & 1100 & 584 & 129 & 171 & $131 \S$ & $5 \S$ & & & \\
\hline 1-3 Totals & & 700 & 364 & 92 & & & & 173 & 122 & 1 \\
\hline
\end{tabular}

$\mathrm{H}=$ hysterectomy; $\mathbf{S}=$ salpingectomy $; \mathrm{L}=$ laparoscopy.

Values significantly different from those for semen: ${ }^{*} P<0.05 ; \dagger P<0.01 ; \ddagger P<0.005 ; \S P<0.001\left(2 \times 2 \chi^{2}\right.$ tests; zero values were not included in the comparisons).

There was an increase in the overall proportion of spermatozoa with normal head form (and no other defects, for example see Fig. 1 of Mortimer, 1981) in the uterus and oviducts, and a decrease in the incidence of spermatozoa with midpiece and/or tail defects. Spermatozoa with simple coiled tails were not considered as abnormal because it is known that this feature may also be caused by osmotic stress (Drevius, 1975); it may also be a feature of senescent spermatozoa. Some spermatozoa with abnormal head forms, but no other obvious signs of abnormality, did, however, reach the uterus and oviducts.

While there was no indication of a further improvement in the proportion of morphologically normal spermatozoa across the uterotubal junction, the summed data for the small numbers

\section{PLATE 1}

Abbreviations: $\mathrm{a}=$ annulus; acr $=$ anterior cap region of the acrosome; bs $=$ basal surface of the head; es = equatorial segment of the acrosome; $\mathrm{m}=$ mitochondrion; $\mathrm{mp}=$ midpiece; pas = postacrosomal sheath; $\mathrm{pp}=$ principal piece of the sperm tail; $\mathrm{pr}=$ posterior ring.

Fig. 1. Spermatozoon with the acrosome breaking down in the anterior cap region (note intact equatorial segment), possibly undergoing an acrosome reaction, giving the cell surface a 'rough' appearance in that region of the head.

Fig. 2. Morphologically normal spermatozoon with a plasmalemma in the process of being lost. The entire surface of the head has a 'rough' appearance, and the outer acrosomal membrane can be seen through a hole in the plasmalemma (arrow).

Fig. 3. Spermatozoon with a normal head shape but completely lacking the plasmalemma and revealing subcellular structures: anterior cap region and equatorial segment of the acrosome, the postacrosomal sheath, posterior ring, basal surface of the head, and mitochondria of the midpiece.

Fig. 4. Otherwise normal spermatozoon (oval-shaped head, smooth cell surface) but with an abnormal midpiece lacking some mitochondria and thereby revealing the axial filament complex of the tail (arrow). 


\section{PLATE 1}
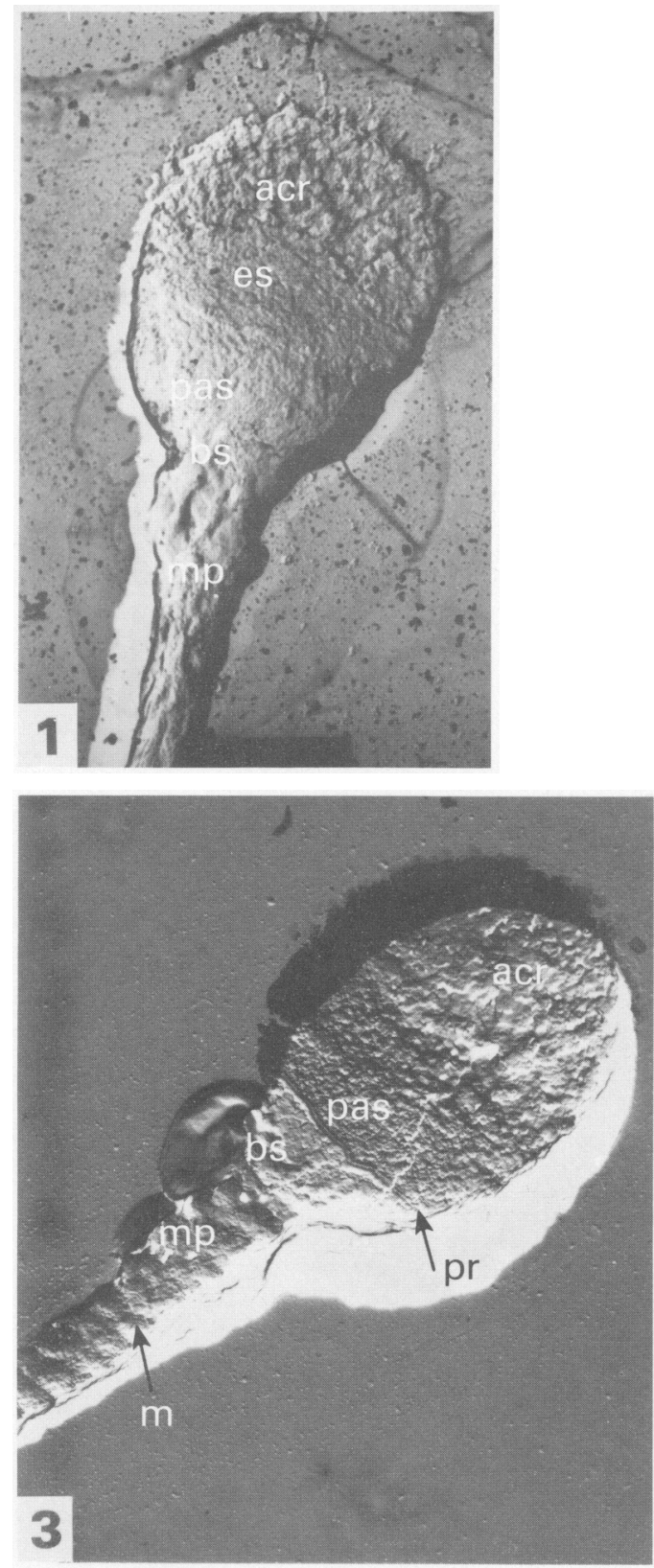

(Facing p. 394)
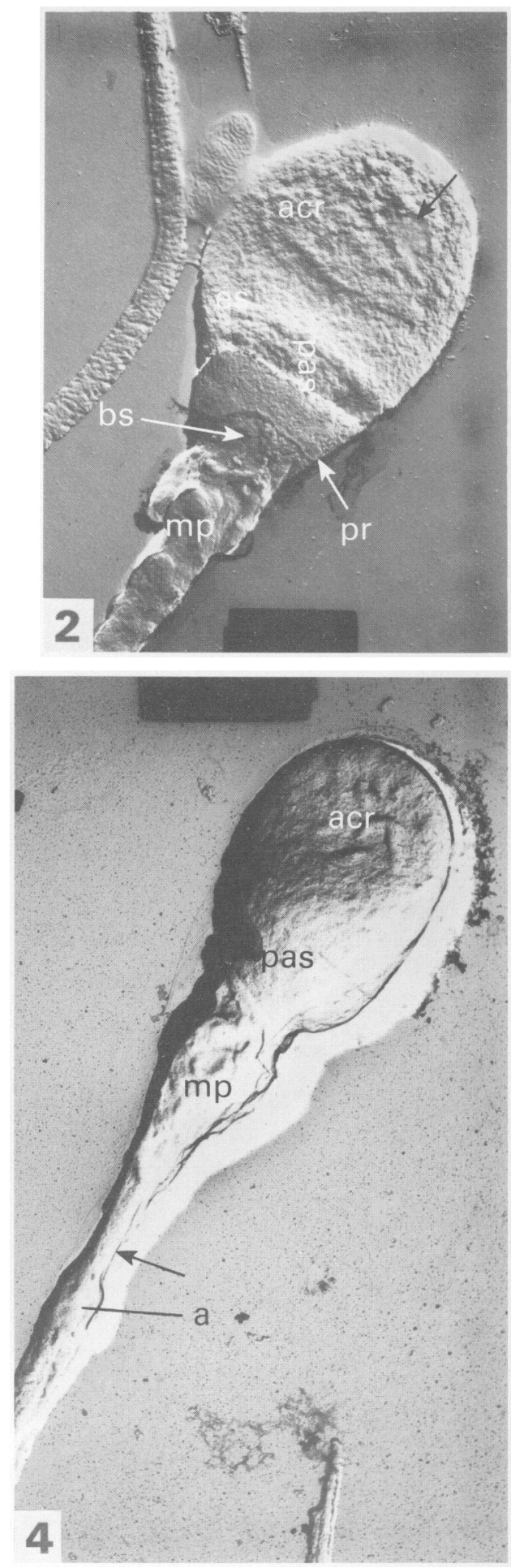
of abnormal spermatozoa do indicate a possible reduction in the incidence of spermatozoa with impaired motile ability in the oviducts $(0.05<P<0.1)$.

Several spermatozoa in the uterine (49/171) and tubal (37/173) samples had a 'rough' surface architecture. Although this appearance may be due to an acrosome reaction in some cells (e.g. Pl. 1, Fig. 1), in others it is clearly due to senescence or post-mortem change (Pl. 1, Figs 2 and 3). This finding indicates that even within a few hours after insemination some spermatozoa which have reached the upper regions of the female tract may be moribund or even dead.

\section{Study 3: In-vitro selection by motility}

\section{Materials and methods}

Twelve semen samples which had characteristics within acceptable ranges (see Eliasson, 1977) were used within $2 \mathrm{~h}$ of ejaculation. Ejaculates with average motility and morphology, selected by visual appraisal of wet preparations before use, were used. A count of the percentage of progressively motile spermatozoa in an aliquot of the semen ('initial' spermatozoa) was made by visual assessment of 100 spermatozoa at a magnification of $\times 400$ (phase-contrast optics), and a smear made for Papanicolaou staining. The semen was then incubated in a special apparatus (Text-fig. 1). The lower chamber of the apparatus was filled with semen through the plastic tubing, and the upper chamber with medium: (Hank's balanced salt solution (Flow Labs) containing $0.3 \%(\mathrm{w} / \mathrm{v}$ ) human serum albumin (fraction V; Sigma, Poole, U.K.)).

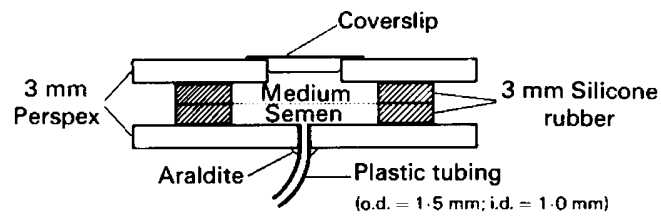

Text-fig. 1. Apparatus (devised by Dr R. W. Kelly) for obtaining highly motile populations of spermatozoa. The upper and lower chambers are separated by a fine nickel mesh $(11 \mu \mathrm{m}$ pore size Micromesh: EMI Electronics Ltd, Electron Tube Division, Ruislip, Middlesex, U.K.). A small nut and bolt through each corner of the two pieces of Perspex hold the apparatus together.

During incubation at $\sim 22^{\circ} \mathrm{C}$ the spermatozoa swim through the nickel mesh into the upper chamber. After $2 \mathrm{~h}$ the sperm population in the upper chamber ('selected' spermatozoa) was aspirated with a Pasteur pipette. The percentage of progressively motile spermatozoa was determined as before, and a smear made for Papanicolaou staining. Ambient temperature was chosen for the incubation because human spermatozoa in seminal plasma retain their motility better at this temperature than at $37^{\circ} \mathrm{C}$ (Appell \& Evans, 1977).

After randomization and coding, the morphology of 200 spermatozoa from each of the 'initial' and 'selected' slides was assessed (by D. M.) at a magnification of $\times 1000$ under oil immersion by bright-field illumination using a Reichert Univar microscope. Sperm morphology was evaluated using a multiple entry system so that for each spermatozoon the morphology of the head, midpiece and tail was classified separately.

\section{Results}

As shown in Table 4, in all but one of the samples there was a sìgnificant improvement in the proportion of progressively motile spermatozoa in the 'selected' population, and in 9 of the samples there was also a significant improvement in the proportion of spermatozoa of normal morphology. In Samples 7 and 9 the improvement in morphology was not significant, and in 
Sample 12 there was a significant increase in the proportion of normal spermatozoa but no apparent change in the proportion of motile cells.

Table 4. The proportions of progressively motile and morphologically normal spermatozoa in the sperm populations before and after selection by swimming through a nickel mesh in 12 experiments

\begin{tabular}{|c|c|c|c|c|c|c|}
\hline \multirow{2}{*}{$\begin{array}{l}\text { Semen } \\
\text { sample } \\
\text { number }\end{array}$} & \multicolumn{3}{|c|}{ Motile spermatozoa $(/ 100)$} & \multicolumn{3}{|c|}{ Normal spermatozoa $(/ 200)$} \\
\hline & Initial & Selected & $\begin{array}{c}\% \text { relative } \\
\text { change }\end{array}$ & Initial & Selected & $\begin{array}{c}\% \text { relative } \\
\text { change }\end{array}$ \\
\hline 1 & 51 & 84 & $+64 \cdot 7^{c}$ & 15 & 37 & $+146 \cdot 7^{b}$ \\
\hline 2 & 35 & 88 & $+151 \cdot 4^{\mathrm{c}}$ & 66 & 147 & $+122 \cdot 7^{\mathrm{c}}$ \\
\hline 3 & 47 & 98 & $+108 \cdot 5^{c}$ & 74 & 164 & $+121 \cdot 6^{c}$ \\
\hline 4 & 40 & 82 & $+105 \cdot 0^{c}$ & 32 & 97 & $+203 \cdot 1^{c}$ \\
\hline 5 & 69 & 86 & $+24 \cdot 6^{b}$ & 104 & 175 & $+68 \cdot 3^{c}$ \\
\hline 6 & 62 & 88 & $+41 \cdot 9^{\mathrm{c}}$ & 141 & 167 & $+18 \cdot 4^{b}$ \\
\hline 7 & 43 & 91 & $+111 \cdot 6^{\mathrm{c}}$ & 107 & 134 & $+25 \cdot 2^{\mathrm{a}}$ \\
\hline 8 & 46 & 78 & $+69 \cdot 6^{\mathrm{c}}$ & 46 & 80 & $+73.9^{c}$ \\
\hline 9 & 48 & 80 & $+66.7^{c}$ & 127 & 151 & $+18.9^{\circ}$ \\
\hline 10 & 42 & 85 & $+102.4^{c}$ & 85 & 149 & $+75 \cdot 3^{c}$ \\
\hline 11 & 48 & 76 & $+58 \cdot 3^{c}$ & 99 & 178 & $+79.8^{c}$ \\
\hline 12 & 56 & 58 & $+3 \cdot 6^{c}$ & 51 & 104 & $+103 \cdot 9^{c}$ \\
\hline $\begin{array}{c}\text { Mean } \\
\pm \text { s.e.m. }\end{array}$ & $\begin{array}{r}48.9 \\
\pm 2.8\end{array}$ & $\begin{array}{r}* 82.8 \\
\pm 2.8\end{array}$ & $\begin{array}{l}+75.69 \\
\pm 12.05\end{array}$ & $\begin{array}{r}+78.9 \\
\pm 11.1\end{array}$ & $\begin{array}{r}+131.9 \\
\pm 12.6\end{array}$ & $\begin{array}{l}+88.15 \\
\pm 15.97\end{array}$ \\
\hline
\end{tabular}

Values with superscript letters indicate significant differences between 'initial' and 'selected' samples: ${ }^{\mathrm{a} P}<0.01,{ }^{\mathrm{b}} P<0.005,{ }^{\mathrm{c}} P<0.001$ (from $2 \times 2 \chi^{2}$ tests performed on actual counts).

${ }^{*} P<0.001$ (Student's $t$ test).

$\dagger P<0.005$ (Student's $t$ test).

Mean values for the 12 experiments showed significant increases in the proportions of both motile and morphologically normal spermatozoa. The mean percentage relative changes for these two types of spermatozoa were statistically indistinguishable, indicating a close correlation between the selection of motile spermatozoa and the increase in the proportion of morphologically normal spermatozoa.

Table 5. Incidence of midpiece and/or tail defects in spermatozoa with normal or abnormal head morphology before and after selection in vitro

\begin{tabular}{|c|c|c|c|c|c|c|}
\hline \multirow{3}{*}{$\begin{array}{l}\text { Morphology of } \\
\text { midpiece and tail }\end{array}$} & \multirow{2}{*}{\multicolumn{2}{|c|}{$\begin{array}{l}\text { 'Initial' spermatozoa } \\
\text { Head morphology (\%) }\end{array}$}} & \multirow{2}{*}{\multicolumn{2}{|c|}{$\frac{\text { 'Selected' spermatozoa }}{\text { Head morphology (\%) }}$}} & \multirow{2}{*}{\multicolumn{2}{|c|}{$\begin{array}{l}\text { Difference between 'initial' } \\
\text { and 'selected' samples }\end{array}$}} \\
\hline & & & & & & \\
\hline & Normal & Abnormal & Normal & Abnormal & Normal & Abnormal \\
\hline Normal & $947(73.6)$ & $541(48.6) \dagger$ & $1583(92.4)$ & $573(83.4)^{\dagger}$ & $P<0.001$ & - \\
\hline Immature & $38(3 \cdot 0)$ & $68(6 \cdot 1) \dagger$ & $36(2 \cdot 1)$ & $34(4.9) \dagger$ & - & $P<0.001$ \\
\hline Midpiece defect & $112(8 \cdot 7)$ & $177(15.9) \dagger$ & $58(3.4)$ & $44(6.4) \dagger$ & $P<0.001$ & $P<0.001$ \\
\hline $\begin{array}{l}\text { Midpiece and } \\
\text { tail defects }\end{array}$ & $90(7 \cdot 0)$ & $253(22.7) \dagger$ & $4(0 \cdot 2)$ & $15(2 \cdot 2) \dagger$ & $P<0.001$ & $P<0.001$ \\
\hline Tail defect & $56(4 \cdot 4)$ & $31(2 \cdot 8)^{*}$ & $5(0 \cdot 3)$ & $6(0.9)$ & $P<0.001$ & $P<0.001$ \\
\hline Coiled tail & $43(3 \cdot 3)$ & $44(3.9)$ & $27(1 \cdot 6)$ & $15(2 \cdot 2)$ & - & $P<0.001$ \\
\hline Total & $1286(53 \cdot 6)$ & $1114(46 \cdot 4) \dagger$ & $1713(71 \cdot 4)$ & $687(28.6)^{\dagger}$ & & 001 \\
\hline
\end{tabular}

Percentages are calculated within head morphology categories. For totals of head types, percentages are calculated with respect to the total number of spermatozoa counted (i.e. 2400 'initial' and 2400 'selected').

Significantly different from value for spermatozoa with normal heads: ${ }^{*} P<0.05,+P<0.001\left(2 \times 2 \chi^{2}\right.$ tests on actual counts). 
Table 5 shows a more detailed analysis of the sperm morphology counts. Among ejaculate ('initial') spermatozoa with an abnormal head form there was a high incidence of midpiece defects and these defects often occurred simultaneously with tail defects. Spermatozoa with coiled tails were considered separately for the same reasons as outlined in Study 2 . Among the 'selected' spermatozoa there were still significantly more spermatozoa of abnormal head form with midpiece defects, but the proportion with tail defects was not different from that for spermatozoa with normal head form.

In the selection of motile spermatozoa, cells with defective midpieces and/or tails, irrespective of head morphology, were clearly at a disadvantage. Coiled-tail or immature spermatozoa (i.e. those with residual cytoplasmic droplets) were only apparently at a disadvantage if they had abnormal head form. The coiled-tail values may reflect the proportion of such spermatozoa which are truly abnormal, but it could also reflect the incidence of the artefact in seminal plasma and the artificial medium.

\section{Discussion}

The results of Studies 1 and 2 confirm the existence of a selection for morphologically normal human spermatozoa within the cervical mucus, the uterine lumen and the Fallopian tubes. The penetration of the cervical mucus is considered to be dependent upon sperm motility (Overstreet \& Katz, 1977; Mortimer, 1978; Insler, Bernstein, Glezerman \& Misgav, 1979). Information on the morphology of the spermatozoa at the site of fertilization is limited. Ahlgren et al. (1974) reported that between 79 and $98 \%$ of spermatozoa recovered from the ampullae were morphologically normal, whilst Asch (1976) stated that no abnormal forms were found in the pouch of Douglas. Our results show that the latter statement is an over-simplification, and that a few 'abnormal' spermatozoa may reach the site of fertilization. This is in accordance with findings in other species (mouse: Krzanowska, 1974; de Boer, van der Hoeven \& Chardon, 1976; rabbit: Mortimer, 1977a, b). However, detailed evaluation of the morphology of spermatozoa recovered from the various parts of the female tract shows that the selection of spermatozoa is largely achieved by reductions in spermatozoa with midpiece, tail, and other defects which might be expected to impair their motility.

Experiments on the selection of motile spermatozoa in vitro by several different systems have been reported (e.g. Botella-Llusia, 1956; Kremer, 1965; Ericsson, Langevin \& Nishino, 1973; Goodall \& Roberts, 1976). Any system has technical problems, but the present apparatus (Text-fig. 1) is considered to be a successful compromise between elimination of the possibility of mixing by convection currents while retaining a 'high transparency' interface. While the possible selection across a simple membrane is not as strict as that exerted by a column of mucus (either in vivo or in vitro) the present system does permit a standardization of the selection mechanism on a long-term basis, a feature impossible with cervical mucus.

The in-vitro selection experiments, with simultaneous multi-parameter scoring of sperm morphology, revealed that spermatozoa with an abnormal head form have a greater incidence of other defects than do spermatozoa with a normal head form. This confirms previous reports of a different distribution of various abnormalities in 'normal' and 'abnormal' spermatozoa (Fujita, Miyoshi \& Tokunaga, 1970; Fredricsson, 1978; Souchier, Czyba \& Grantham, 1978). The absence of a significant increase in the incidence of spermatozoa with abnormal head form but otherwise normal morphology in the presence of such a highly significant difference in the general incidence of spermatozoa with abnormal head form was unexpected. However, 4 of the semen samples did show a relatively high incidence of what would be considered borderline pyriform heads (Samples 1, 4, 8 and 12) with three of these (Samples 1, 8 and 12) also containing numerous borderline tapering forms. In these men the existence of 'borderline abnormal' head forms (i.e. those only slightly different from the modal oval form seen in the 
general population) may not be important, and if such spermatozoa have normal motor apparatus they are, essentially, 'normal'. The parameters of head shape are known to be genetically controlled in rabbits and mice and vary both between and within strains (see Beatty, $1970,1975)$. The presence of a residual cytoplasmic droplet, at least in spermatozoa with a 'normal' head form, did not seem to affect their ability to migrate in vitro, suggesting that in these spermatozoa epididymal maturation has been completed, at least in so far as the motor apparatus is concerned. Whether such spermatozoa would be able to fertilize eggs is not known. The selection of spermatozoa by their swimming abilities alone did result in a selection for morphologically normal cells, with the categories of spermatozoa at a disadvantage closely paralleling those suffering the same fate in vivo.

The ability to evaluate the proportion of spermatozoa in a semen sample which could successfully negotiate the female tract and subsequently fertilize eggs would be of great value for semen analysis. The present study permits prediction of which types of spermatozoa might be expected to gain the site of fertilization. Further information on the intrinsic fertility of spermatozoa which do reach the Fallopian tubes while possessing various atypical morphological characteristics is now required. It is known, however, that morphologically abnormal (Smith, Oura \& Zamboni, 1970) and diploid (Maudlin \& Fraser, 1978) mouse spermatozoa are able to fertilize eggs, and it is probable that diploid rabbit spermatozoa are also intrinsically fertile (Mortimer, 1979).

During most of these studies D.M. was supported by a Wellcome Trust Interdisciplinary Linked Fellowship which also supported the invaluable technical assistance of E.E.L. For part of the in-vivo work A.A.T. was in receipt of a Wellcome Trust Surgical Fellowship. Technical assistance in various aspects of the studies by $\mathrm{Mr} \mathrm{K}$. Donachie and Mrs C. Reid is gratefully acknowledged, as are the efforts of $\mathrm{Mr} \mathrm{F}$. M. Johnson with the electron micrography. The manuscript was typed by Ms R. Carpenter.

\section{References}

Ahlgren, M., Boström, K. \& Malmqvist, R. (1974) Sperm transport and survival in women with special reference to the Fallopian tube. In Sperm Transport, Survival and Fertilizing Ability in Vertebrates, Vol. 26, pp. 183-200. Eds E. S. E. Hafez \& C. G. Thibault. INSERM, Paris.

Appell, R.A. \& Evans, P.R. (1977) The effect of temperature on sperm motility and viability. Fert. Steril. 28, 1329-1332.

Asch, R.H. (1976) Laparoscopic recovery of sperm from peritoneal fluid, in patients with negative or poor Sims-Huhner test. Fert. Steril. 27, 1111-1114.

Beatty, R.A. (1970) The genetics of the mammalian gamete. Biol. Rev. 45, 73-120.

Beatty, R.A. (1975) Genetics of animal spermatozoa. In Gamete Competition in Plants and Animals, pp. 61-68. Ed. D. L. Mulcahy. North-Holland, Amsterdam.

Bergman, P. (1955) Spermigration and its relation to the morphology and motility of spermatozoa. Int. J. Fertil. 1, 45-54.

Botella-Llusia, J. (1956) Measurement of linear progression of the human spermatozoon as an index of male fertility. Int. J. Fertil. 1, 113-130.

Clavert, A., Brun, B. \& Bollecker, G. (1975) Teratospermie et migration des spermatoides in vitro et in vivo. C. r. Séanc. Soc. Biol. 169, 1281-1284.
Davajan, V., Nakamura, R.M. \& Kharma, K. (1970) Spermatozoan transport in cervical mucus. Obstet. gynec. Surv. 25, 1-43.

de Boer, P., van der Hoeven, A. \& Chardon, J.A.P. (1976) The production, morphology, karyotypes and transport of spermatozoa from tertiary trisomic mice and the consequences for egg fertilization. J. Reprod. Fert. 48, 249-256.

Drevius, L.-O. (1975) Permeability of the bull-sperm membrane. In The Functional Anatomy of the Spermatozoon, pp. 373-383. Ed. B. A. Afzelius. Pergamon Press, Oxford.

Eliasson, R. (1975) Analysis of semen. In Progress in Infertility, 2nd edn, Ch. 33, pp. 691-713. Eds S. J. Behrman \& R. W. Kistner. Little, Brown \& Co., Boston.

Eliasson, R. (1977) Semen analysis and laboratory workup. In Male Infertility, Workup, Treatment and Research, pp. 169-188. Eds A. T. K. Cockett \& R. L. Urry. Grune \& Stratton, New York.

Ericsson, R.J., Langevin, C.N. \& Nishino, M. (1973) Isolation of fractions rich in human $\mathrm{Y}$ sperm. Nature, Lond. 246, 421-424.

Fredricsson, B. (1978) On the development of different morphologic abnormalities of human spermatozoa. Andrologia 10, 43-48.

Fredricsson, B. \& Björk, G. (1977) Morphology of 
postcoital spermatozoa in the cervical secretion and its clinical significance. Fert. Steril. 28, 841-845.

Fujita, T., Miyoshi, M. \& Tokunaga, J. (1970) Scanning and transmission electron microscopy of human ejaculate spermatozoa with special reference to their abnormal forms. Z. Zellforsch. mikrosk. Anat. 105, 483-497.

Goodall, H. \& Roberts, A.M. (1976) Differences in motility of human X-and Y-bearing spermatozoa. $J$. Reprod. Fert. 48, 433-436.

Insler, V., Bernstein, D., Glezerman, M. \& Misgav, N. (1979) Correlation of seminal fluid analysis with mucus-penetrating ability of spermatozoa. Fert. Steril. 32, 316-319.

Kremer, J. (1965) A simple sperm penetration test. Int. J. Fertil. 10, 209-215.

Krzanowska, H. (1974) The passage of abnormal spermatozoa through the uterotubal junction of the mouse. J. Reprod. Fert. 38, 81-90.

Maathuis, J.B. \& Aitken, R.J. (1978) Cyclic variation in concentrations of protein and hexose in human uterine flushings collected by an improved technique. J. Reprod. Fert. 52, 289-295.

Maudlin, I. \& Fraser, L.R. (1978) The effect of sperm and egg genotype on the incidence of chromosomal anomalies in mouse embryos fertilized in vitro. $J$. Reprod. Fert. 52, 107-112.

Moghissi, K.S. (1977) Sperm migration through the human cervix. In The Uterine Cervix in Reproduction, pp. 146-165. Eds V. Insler \& G. Bettendorf. Georg Thieme Publishers, Stuttgart.

Mortimer, D. (1977a) Electron and light microscope studies of mammalian spermatozoa. Ph.D. Thesis, University of Edinburgh.

Mortimer, D. (1977b) The survival and transport to the site of fertilization of diploid rabbit spermatozoa. $J$. Reprod. Fert. 51, 99-104.

Mortimer, D. (1978) Selectivity of sperm transport in the female genital tract. In Spermatozoa, Antibodies and Infertility, Ch. 5, pp. 37-53. Eds J. Cohen \& W. F. Hendry. Blackwell Scientific Publications, Oxford.

Mortimer, D. (1979) Functional anatomy of haploid and diploid rabbit spermatozoa. Arch. Androl. 2, 13-20.

Mortimer, D. (1981) The assessment of human sperm morphology in surface replica preparations for transmission electron microscopy. Gamete Res. 4, 113-119.

Overstreet, J.W. \& Katz, D.F. (1977) Sperm transport and selection in the female genital tract. In Development in Mammals, Vol. 2, pp. 31-65. Ed. M. H. Johnson. North-Holland, Amsterdam.

Papanicolaou, G.N. (1942) A new procedure for staining vaginal smears. Science, N.Y. 95, 438-439.

Perry, G., Glezerman, M. \& Insler, V. (1977) Selective filtration of abnormal spermatozoa by the cervical mucus in vitro. In The Uterine Cervix in Reproduction, pp. 118-127. Eds V. Insler \& G. Bettendorf. Georg Thieme Publishers, Stuttgart.

Smith, D.M., Oura, C. \& Zamboni, L. (1970) Fertilizing ability of structurally abnormal spermatozoa. Nature, Lond. 227, 79-80.

Souchier, C., Czyba, J.C. \& Grantham, R. (1978) Difficulties in morphologic classification of human spermatozoa. J. Reprod. Med. 21, 244-248.

Received 7 May 1981 